\title{
FEA Analysis of Double Tube Heat Exchanger on Variable Baffle Pitch for Optimizing Thermal Efficiency
}

\author{
Anil Kumar \\ M. Tech. Scholar \\ Sagar Institute of Science and \\ Technology, Bhopal (M.P.), \\ India \\ skmr729@gmail.com
}

\author{
Rashmi Dwivedi \\ Assit. Professor \\ Sagar Institute of Science and \\ Technology, Bhopal (M.P.) \\ India \\ rashmidwivedi29@gmail.com
}

\author{
Sanjay Chhalotre \\ Assit. Professor \\ Sagar Institute of Science and \\ Technology, Bhopal (M.P.) \\ India
}

\begin{abstract}
The main objective of this work is to compare different configurations of helical baffles in the cold fluid side of a double tube heat exchanger. For this analysis double pipe heat exchangers are divided into three different domains such as two fluid domains hot fluid in the inner tube and cold fluid in the outer pipe and a solid domain as helical baffles on inner tube of hot fluid. The hot water flows inside the heat exchanger tube, while the cold fluid flows in the outer side in the direction of counter flow. Mass flow rate cold fluid was varied from $0.1 \mathrm{~kg} / \mathrm{s}$ to $0.3 \mathrm{~kg} / \mathrm{s}$ while the flow rate in the inner tube i.e. hot water was kept constant at 0.1 $\mathrm{kg} / \mathrm{s}$. the inlet temperature of hot fluid taken as $40^{\circ} \mathrm{C}$ while Cold fluid inlet temperature taken as $15^{\circ} \mathrm{C}$. The fluent software is used to calculate the fluid flow and heat transfer in the computational domains. The governing equations are iteratively solved by the finite volume formulation with the SIMPLE algorithm. Results show that that the maximum temperature drop of $10.9^{\circ} \mathrm{C}$ for hot fluid and the maximum temperature rise of $11.9^{\circ} \mathrm{C}$ for cold fluid are observed at 0.3 $\mathrm{kg} / \mathrm{sec}$ mass flow rate for double pipe heat exchanger with double helical baffles. It has been also observed that the heat transfer coefficient increasing with the increasing in the mass flow rate of cold fluid. The overall heat transfer coefficients differ significantly by $20.4 \%$ at same mass flow rate, because the considerable difference between heat transfer surface area on the inner and outer side of the tube resulting in a prominent thermal enhancement of the cold fluid.
\end{abstract}

Keywords: CFD, helical baffle, ANSYS, heat exchanger,

\section{INTRODUCTION}

A heat exchanger is a device that is used to transfer thermal energy between two or more fluids, between a solid surface and a fluid, or between solid particulates and a fluid, at different temperatures and in thermal contact.
In heat exchangers, there are usually no external heat and work interactions. Typical applications involve heating or cooling of a fluid stream and evaporation or condensation of single or Multi component fluid streams. In most heat exchangers, heat transfer between fluids takes place through a separating wall or into and out of a wall in a transient manner. In many heat exchangers, the fluids are separated by a heat transfer surface, and ideally they do not mix or leak. Such exchangers are referred to as direct transfer type, or simply recuperator. In contrast, exchangers in which there is intermittent heat exchange between the hot and cold fluids via thermal energy storage and release through the exchanger surface or matrix are referred to as indirect transfer type, or simply regenerators. Such exchangers usually have fluid leakage from one fluid stream to the other due to pressure differences and matrix rotation/valve switching.

\section{LITERATURE REVIEW}

Qianmei Fu at el. [1] In this study, the effects of structure ratio of the heat exchanger and the entrance velocity of S$\mathrm{CO} 2$ on heat transfer and flow resistance are investigated numerically. The results show that the velocity of S-CO2 plays a major role in a small flow channel determining the overall performance. It concludes that reducing the flow resistance and improve the performance of heat transfer needs to be considered first in the optimal design of a double-pipe heat exchanger using $\mathrm{S}-\mathrm{CO} 2$ as working fluid.

Ganesh Kumar Poongavanam at el. [2] the study is extended to analyze the variations in CHTC, the pressure drop of the nan fluid (multi-walled carbon nanotubes. The 
experiments were carried out at different volume concentrations $(0.2 \%, 0.4 \%$, and $0.6 \%)$ of the nan fluids. Experimental results showed that shot peening in tube surfaces has an appreciable effect on the performance of flow behavior and heat transfer. The CHTC of the nanofluid containing $0.6 \%$ of MWCNT nano materials is improved to a maximum of $\sim 115 \%$ at a mass flow rate of $0.04 \mathrm{~kg} / \mathrm{sec}$. Enhancement in thermal conductivity up to $30.59 \%$ was achieved with the MWCNT volume concentration of $0.6 \%$ and a temperature range from 30 to $50^{\circ} \mathrm{C}$.

Rafał Andrzejczyk, et al. [3] in this paper, the possibility of heat transfer enhancement in the U-bend exchanger was presented. Experimental research has been carried out for four individual heat exchanger constructions i.e. plain tube in tube, turbulized tube in tube, plain U-bend and Ubend with turbulator.

Anas El Maakoul at el. [4] In this paper, the design and thermo-hydraulic performance of a double pipe heat exchanger with helical baffles in the annulus side are investigated numerically. In the three dimensional computational fluid dynamics model, using the software FLUENT, have been performed to investigate the annulus side fluid flow, heat transfer coefficient and pressure drop for different configurations.

\section{OBJECTIVE}

There are following objective of the present work.

1. The main objective of the present work to performed three dimensional Computational Fluid dynamics analysis to evaluate the velocity, temperature, overall heat transfer coefficient for double pipe heat exchanger under condition of counter flow.

2. To design the different model of double pipe heat exchanger using Ansys design modular.

3. To perform CFD analysis for heat transfer in the heat exchanger under different operation conditions.

4. To compare the simulated results for different models of double pipe heat exchanger and propose best solution for better heat transfer

\section{Methodology}

A. Analysis of Heat Exchangers

Heat exchangers are commonly used in practice, and an engineer often finds himself or herself in a position to select a heat exchanger that will achieve a specified temperature change in a fluid stream of known mass flow rate, or to predict the outlet temperatures of the hot and cold fluid streams in a specified heat exchanger. In upcoming sections, we will discuss the two methods used in the analysis of heat exchangers. Of these, the log mean temperature difference (or LMTD) method is best suited for the first task and the effectiveness-NTU method for the second task as just stated. But first we present some general considerations. Heat exchangers usually operate for long periods of time with no change in their operating conditions. Therefore, they can be modeled as steadyflow devices. As such, the mass flow rate of each fluid remains constant, and the fluid properties such as temperature and velocity at any inlet or outlet remain the same. Also, the fluid streams experience little or no change in their velocities and elevations, and thus the kinetic and potential energy changes are negligible.

\section{B. Mathematical relation}

The idealizations stated above are closely approximated in practice, and they greatly simplify the analysis of a heat exchanger with little sacrifice of accuracy.

C. Assumption

1. Steady operating conditions exist.

2. The heat exchanger is well insulated so that hear loss to the surrounding is negligible and thus heat transfer from the hot fluid is equal to the heat transfer to the cold fluid.

3. Change in kinetic and potential energies of fluid streams are negligible.

4. There is no fouling, and

5. Fluid properties are constant.

Apart from above assumptions the first law of thermodynamics requires that the rate of heat transfer from the hot fluid be equal to the rate of heat transfer to the cold one. That is,

And

$$
\dot{\mathrm{Q}}=\dot{\mathrm{m}}_{\mathrm{c}} \mathrm{C}_{\mathrm{pc}}\left(\mathrm{t}_{\mathrm{c}, \text { out }}-\mathrm{t}_{\mathrm{c}, \mathrm{in}}\right)
$$

$$
\dot{\mathrm{Q}}=\dot{\mathrm{m}}_{\mathrm{h}} \mathrm{C}_{\mathrm{pc}}\left(\mathrm{t}_{\mathrm{h}, \mathrm{out}}-\mathrm{t}_{\mathrm{h}, \mathrm{in}}\right)
$$

Where the subscripts $\mathrm{c}$ and $\mathrm{h}$ stand for cold and hot fluids, respectively, and

$$
\begin{gathered}
\dot{\mathrm{m}}_{\mathrm{c}}, \dot{\mathrm{m}}_{\mathrm{h}}=\text { mass flow rates } \\
\mathrm{C}_{\mathrm{pc},}, \mathrm{C}_{\mathrm{ph}}=\text { specific heats } \\
\mathrm{t}_{\mathrm{c}, \text { out }}, \mathrm{t}_{\mathrm{h}, \text { out }}=\text { outet temperature } \\
\mathrm{t}_{\mathrm{c}, \text { in }}, \mathrm{t}_{\mathrm{h}, \text { in }}=\text { inlet temperature }
\end{gathered}
$$

Note that the heat transfer rate Qis taken to be a positive quantity, and its direction is understood to be from the hot fluid to the cold one in accordance with the second law of thermodynamics. 
In heat exchanger analysis, it is often convenient to combine the product of the mass flow rate and the specific heat of a fluid into a single quantity. This quantity is called the heat capacity rate and is defined for the hot and cold fluid streams as

$$
\mathrm{C}_{\mathrm{h}}=\dot{\mathrm{m}}_{\mathrm{h}} \mathrm{C}_{\mathrm{ph}} \text { and } \mathrm{C}_{\mathrm{c}}=\dot{\mathrm{m}}_{\mathrm{c}} \mathrm{C}_{\mathrm{ph}}
$$

The heat capacity rate of a fluid stream represents the rate of heat transfer needed to change the temperature of the fluid stream by $1^{\circ} \mathrm{C}$ as it flows through a heat exchanger. Note that in a heat exchanger, the fluid with a large heat capacity rate will experience a small temperature change, and the fluid with a small heat capacity rate will experience a large temperature change. Therefore, doubling the mass flow rate of a fluid while leaving everything else unchanged will halve the temperature change of that fluid.

$$
\begin{aligned}
& \dot{Q}=C_{c}\left(t_{c, \text { out }}-t_{c, \text { in }}\right) \\
& \dot{Q}=C_{h}\left(t_{h, \text { out }}-t_{h, \text { in }}\right)
\end{aligned}
$$

That is, the heat transfer rate in a heat exchanger is equal to the heat capacity rate of either fluid multiplied by the temperature change of that fluid. Two special types of heat exchangers commonly used in practice are condensers and boilers. One of the fluids in a condenser or a boiler undergoes a phase-change process, and the rate of heat transfer is expressed as

$$
\dot{\mathrm{Q}}=\dot{\mathrm{m}} \mathrm{h}_{\mathrm{fg}}
$$

Where mthe rate of evaporation or condensation of the fluid and hfg is is the enthalpy of vaporization of the fluid at the specified temperature or pressure. An ordinary fluid absorbs or releases a large amount of heat essentially at constant temperature during a phase-change process. The heat capacity rate of a fluid during a phase-change process must approach infinity since the temperature change is practically zero. That is, $\mathrm{C}=\dot{\mathrm{m}}_{\mathrm{p}} \rightarrow \infty$ when $\Delta \mathrm{T} \rightarrow 0$ so that the heat transfer rate $\dot{Q}=\dot{\mathrm{m}} \mathrm{C}_{\mathrm{p}} \Delta \mathrm{T}$ is a finite quantity. Therefore, in heat exchanger analysis, a condensing or boiling fluid is conveniently modeled as a fluid whose heat capacity rate is infinity. The rate of heat transfer in a heat exchanger can also be expressed in an analogous manner to Newton's law of cooling as

$$
\dot{\mathrm{Q}}=\mathrm{UA}_{\mathrm{s}} \Delta \mathrm{T}_{\mathrm{m}}
$$

Where $\mathrm{U}$ is the overall heat transfer coefficient, as is the heat transfer area, and $\Delta \mathrm{T}_{\mathrm{m}}$ is an appropriate average temperature difference between the two fluids. Here the surface area as can be determined precisely using the dimensions of the heat exchanger. However, the overall heat transfer coefficient $U$ and the temperature difference $\Delta \mathrm{T}$ between the hot and cold fluids, in general, are not constant and vary along the heat exchanger.

The average value of the overall heat transfer coefficient can be determined as described in the preceding section by using the average convection coefficients for each fluid. It turns out that the appropriate form of the mean temperature difference between the two fluids is logarithmic in nature.

\section{Heat transfer coefficient}

Heat transfer coefficient is a quantitative characteristic of convective heat transfer between a fluid medium and the surface flowed over by the fluid.

$$
h=\frac{\dot{Q}}{T_{w}-T_{\text {bulk }}}
$$

Where

$$
T_{\text {bulk }}=\frac{\int \rho C_{p} v_{\text {fluid }} T d A}{\int \rho C_{p} v_{\text {fluid }} d A}
$$

$\mathrm{T}_{\mathrm{bulk}}=$ flow weighted average temperature of the fluid $\mathrm{T}_{\mathrm{w}}=$ surface temperature near the wall

$\dot{Q}=$ heat transfer rate

$\mathrm{h}=$ heat transfer coefficient

\section{a. The mean annulus side fluid velocity is defined by}

Annulus side velocity and Reynolds number

$$
u_{a}=\frac{\dot{m}_{a}}{\rho_{a} A_{\text {cross }}}
$$

Where $\dot{m}_{a}$ is the mass flow rate $\rho_{a}$ water density in the annulus side and $A_{\text {cross }}$ represents the characteristic cross-section area.

\section{b. For a helically baffles annulus side}

$$
A_{\text {cross }}=0.5 B\left(D_{s}-D_{o}\right)
$$

Where $B$ is the baffle spacing, $D_{s}$ is the internal diameter of the annulus side, $D_{0}$ the external diameter of the inner tube side. With the mean velocity value, the Reynolds number for the annulus side is determined by:

$$
R_{e}=\frac{\rho_{a} u_{a} D_{o}}{\mu_{a}}
$$

With $\mu_{a}$ the dynamic viscosity in the annulus side.

\section{c. Heat transfer rate}

Heat transfer rate of the annulus side fluid (cool fluid):

$$
Q_{a}=\dot{m}_{a} c_{p, a}\left(T_{a}^{\text {out }}-T_{a}^{\text {in }}\right)
$$

Heat transfer rate of the tube side fluid (warm fluid):

$$
Q_{t}=\dot{m}_{t} c_{p, t}\left(T_{t}^{\text {out }}-T_{t}^{\text {in }}\right)
$$


$\dot{m}$ is the flow rate, $\mathrm{T}$ the temperature, $\mathrm{c}_{\mathrm{p}}$ the specific heat. The subscript a $\& \mathrm{t}$ refers respectively to the annulus side and inner tube side; superscript 'in' and 'out' stand for the values at the inlet and outlet respectively. The physical properties are evaluated at the average temperature of the inlet and outlet for each side of the heat exchanger.

\section{d. Nusselt number:}

The Nusselt number for the annulus side is:

$$
N u=\frac{h_{a} D_{h}}{k}=0.023 \operatorname{Re}^{0.8} \operatorname{Pr}^{0.4}
$$

Where $h_{a}$ is the annulus side heat transfer coefficient, $D_{h}$ equivalent hydraulic diameter, $\mathrm{k}$ the thermal conductivity of the fluid.

The expression for drop through both sides

$$
\Delta p=4 f \frac{L}{D} \rho \frac{\mu^{2}}{2}
$$

Where $\mathrm{f}=$ friction factor depends on the roughness of the tube material $f=0.00014+\frac{0.125}{r e^{0.32}}$

\section{e. The turbulence kinetic energy}

Turbulence kinetic energy $k$ is the kinetic energy per unit mass of the turbulent fluctuations $u_{i}^{\prime}$ The SI unit of $\mathrm{k}$ is $\mathrm{J} / \mathrm{kg}=\mathrm{m}^{2} / \mathrm{s}^{2}$

$K \stackrel{\text { def }}{=} \frac{1}{2} \overline{u_{\imath}^{\prime} u_{l}^{\prime}}=\frac{1}{2}\left(\overline{u_{x}^{\prime 2}}+\overline{u_{y}^{, 2}}+\overline{u_{z}^{\prime 2}}\right)=\frac{3}{2} \overline{u^{\prime 2}}$

Nusselt number for both inner tube and annulus side calculated using the following correlation.

$$
N u=0.023 \operatorname{Re}^{0.8} \operatorname{Pr}^{1 / 3}
$$

The expression to calculate pressure drop through both sides is:

$$
\Delta p=4 f \frac{L}{D} \rho \frac{u^{2}}{2}
$$

The friction factor depends on the roughness of the tube material, the following correlation

$$
f=0.0014+\frac{0.125}{R e^{0.32}}
$$

\section{E. Computational fluid dynamics analysis}

Computational fluid dynamics is the analysis of systems involving fluid flow, heat transfer by use of computer based simulation. The technique is very powerful and spans a wide range of industrial and non-industrial application areas. In the present work computational fluid dynamics analysis is carried out using Ansys fluent for double pipe heat exchanger. The governing equations such as continuity equation, momentum equation, energy equations, $\mathrm{K}$ equation and $\varepsilon$ equations are used to perform this computational analysis. Computational fluid dynamics are structured around the numerical algorithms that can deal with fluid flow problems. In order to provide easy access to their solving power all Computational fluid dynamics packages include sophisticated user interfaces to input problem parameters and to examine the results. Hence three main elements are used to solve the Computational fluid dynamics problems.

1) Pre-processor,

2) Solver and

3) Post-processor.

1. Pre-processor

Pre-processing consists of the input of a flow problem to a Computational fluid dynamics program by means of a user friendly interface and the subsequent transformation of this input into a form suitable for use by the solver. The user activities at the pre-processing stage involve:

- Definition of the geometry of the region of interest: the computational domain.

- Grid generation - the sub-division of the domain into a number of smaller: a grid (or mesh) of cells (or control volumes or elements).

- Selection of the physical and chemical phenomena that need to be modeled.

- Definition of fluid properties.

- Specification of appropriate boundary conditions.

The solution to a flow problem (velocity, pressure, temperature etc.) is defined at nodes inside each cell. The accuracy of a CFD solution is governed by the number of cells in the grid. In general the larger the numbers of cells better the solution accuracy A substantial amount of basic development work still needs to be done before these techniques are robust enough to be incorporated into commercial CFD codes.

\section{Solver}

There are three distinct streams of numerical solution techniques: finite difference, finite element and spectral methods. In Computational fluid dynamics problems a special finite difference formulation such as CFX/ANSYS, FLUENT, PHOENICS and STAR-CD.

In this step the numerical algorithm consists of the following steps:

- Integration of the governing equations of fluid flow over all the (finite) control volumes of the domain.

- Discretization - conversion of the resulting integral equations into a system of algebraic equations.

- Solution of the algebraic equations by an iterative method. 
The resulting statements express the (exact) conservation of relevant properties for each finite size cell. The conservation of a general flow variable $\varphi$, e.g. a velocity component or enthalpy, within a finite control volume can be expressed as a balance between the various processes tending to increase or decrease it.

3. Post-processor

Further processing and viewing of the results in this stage we may wish to see:

- Geometry domain

- Line and shaded contour plots

- Vector plots

- contour diagrams

More recently these facilities may also include animation for dynamic result display and in addition to graphics all codes produce trusty alphanumeric output and have data export facilities for further manipulation.

F. Algorithm used for Computational fluid dynamics analysis

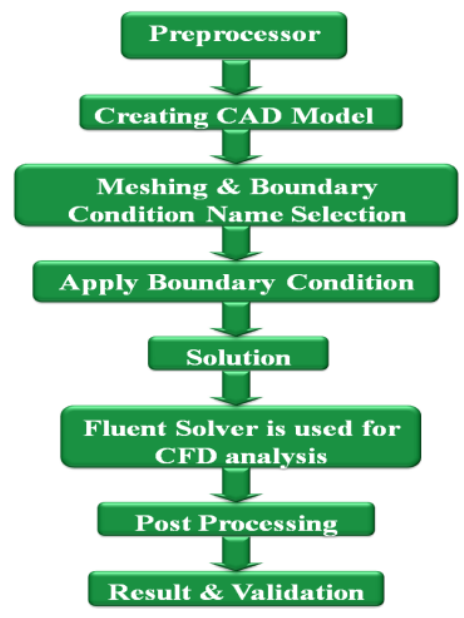

Fig. 1 Algorithm used for Computational fluid dynamics analysis

\section{G. Governing Equations}

\section{a. Conservation of mass or continuity equation}

The equation for conservation of mass, or continuity equation, can be written as follows:

$$
\frac{\partial \rho}{\partial t}+\nabla \cdot(\rho \vec{v})=S_{m}
$$

Where $S_{m}=$ mass added to the continuous phase or any user defined sources.

For $2 \mathrm{D}$ axisymmetric geometries, the continuity equation is given by

$$
\frac{\partial \rho}{\partial t}+\frac{\partial}{\partial x}\left(\rho v_{x}\right)+\frac{\partial}{\partial r}\left(\rho v_{r}\right)+\frac{\rho v_{r}}{r}=S_{m}
$$

Where $x$ is the axial coordinate, $r$ is the radial coordinate, $v_{x}$ is the axial velocity, and $v_{r}$ is the radial velocity.

\section{b. Momentum Conservation Equations}

Conservation of momentum in an inertial reference frame is described by

$$
\frac{\partial}{\partial t}(\rho \vec{v})+\nabla \cdot(\rho \vec{v} \vec{v})=-\nabla p+\nabla \cdot(\overline{\bar{\tau}})+\rho \vec{g}+\vec{F}
$$

Where $\mathrm{p}=$ static pressure

$\overline{\bar{\tau}}=$ stress tensor,

$\rho \vec{g}=$ gravitational body force and

$\vec{F}=$ external body forces

The stress tensor $\overline{\bar{\tau}}$ is given by

$$
\overline{\bar{\tau}}=\mu\left[\left(\nabla \vec{v}+\nabla \vec{v}^{\mathrm{T}}\right)-\frac{2}{3} \nabla \cdot \vec{v} I\right]
$$

where $\mu=$ molecular viscosity

$I=$ unit tensor,

For 2D axisymmetric geometries, the axial and radial momentum conservation equations are given by

$$
\begin{aligned}
\frac{\partial}{\partial x}\left(\rho v_{x}\right)+\frac{1}{r} \frac{\partial}{\partial x}\left(r \rho v_{x} v_{x}\right) & +\frac{1}{r} \frac{\partial}{\partial r}\left(r \rho v_{r} v_{r}\right) \\
& =-\frac{\partial p}{\partial x}+\frac{1}{r} \frac{\partial}{\partial x}\left[r \mu\left(2 \frac{\partial v_{x}}{\partial x}-\frac{2}{3}(\nabla \cdot \vec{v})\right)\right] \\
& +\frac{1}{r} \frac{\partial}{\partial r}\left[r \mu\left(\frac{\partial v_{x}}{\partial r}+\frac{\partial v_{r}}{\partial x}\right)\right]+F_{x}
\end{aligned}
$$

And

$$
\begin{aligned}
\frac{\partial}{\partial t}\left(\rho v_{r}\right)+\frac{1}{r} \frac{\partial}{\partial x}\left(r \rho v_{x} v_{r}\right) & +\frac{1}{r} \frac{\partial}{\partial r}\left(r \rho v_{r} v_{r}\right) \\
& =-\frac{\partial p}{\partial r}+\frac{1}{r} \frac{\partial}{\partial x}\left[r \mu\left(\frac{\partial v_{r}}{\partial x}+\frac{\partial v_{x}}{\partial r}\right)\right] \\
& +\frac{1}{r} \frac{\partial}{\partial r}\left[r \mu\left(2 \frac{\partial v_{r}}{\partial r}-\frac{2}{3}(\nabla \cdot \vec{v})\right)\right]-2 \mu \frac{v_{r}}{r^{2}} \\
& +\frac{2 \mu}{3 r}(\nabla \cdot \vec{v})+\rho \frac{v_{z}^{2}}{r}+F_{r}
\end{aligned}
$$

Where

$$
\nabla \cdot \vec{v}=\frac{\partial v_{x}}{\partial x}+\frac{\partial v_{r}}{\partial r}+\frac{v_{r}}{r}
$$

Where $v_{x}=$ Axial velocity

$v_{r}=$ Radial velocity

$v_{z}=$ swirl velocity

4.7.3 Energy Equation:

The energy equation for the mixture takes the following form:

$$
\frac{\partial}{\partial t} \sum_{k=1}^{n}\left(\alpha_{k} \rho_{k} E_{k}\right)+\nabla \cdot \sum_{k=1}^{n}\left(\alpha_{k} \vec{v}_{k}\left(\rho_{k} E_{k}+p\right)\right)=\nabla \cdot\left(k_{e f f} \nabla T\right)+S_{E}
$$

where $k_{\text {eff }}=$ effective conductivity

$S_{E}=$ volumetric heat sources

Where

$$
E_{k}=h_{k}-\frac{p}{\rho k}+\frac{v_{k}^{2}}{2}
$$

$E_{k}=h_{k}$ for an incompressible phase and $h_{k}=$ sensible enthalpy for phase $k$ 


\section{$k-\in$ model:}

The turbulence kinetic energy, $k$, and its rate of dissipation, $\in$, are obtained from the following transport equations:

$$
\begin{aligned}
\frac{\partial}{\partial t}(\rho k)+\frac{\partial}{\partial x_{i}}\left(\rho k v_{i}\right) & =\frac{\partial}{\partial x_{j}}\left[\left(\mu+\frac{\mu_{t}}{\sigma_{k}}\right) \frac{\partial k}{\partial x_{j}}\right]+G_{k}+G_{b}-\rho \\
& \in-Y_{M}+S_{k}
\end{aligned}
$$

and

$$
\begin{aligned}
\frac{\partial}{\partial t}(\rho \in)+\frac{\partial}{\partial x_{i}}\left(\rho \in v_{i}\right) & \\
= & \frac{\partial}{\partial x_{j}}\left[\left(\mu+\frac{\mu_{t}}{\sigma_{\epsilon}}\right) \frac{\partial \in}{\partial x_{j}}\right]+C_{1 \in} \frac{\epsilon}{k}\left(G_{k}+C_{3 \epsilon} G_{b}\right) \\
& -C_{2 \in} \rho \frac{\epsilon^{2}}{k}+S_{\epsilon}
\end{aligned}
$$

In these equations, $G_{k}$ represents the generation of turbulence kinetic energy due to the mean velocity gradients,

$G_{b}$ is the generation of turbulence kinetic energy due to buoyancy,

$Y_{M}$ represents the contribution of the fluctuating dilatation in compressible turbulence to the overall dissipation rate,

$C_{1 \in}, C_{2 \in}$, and $C_{3 \in}$ are constant.

$\sigma_{k}$ and $\sigma_{\epsilon}$ are turbulent Prandtl numbers for $\mathrm{k}$ and $\epsilon$,

$S_{k}$ And $S_{\in}$ are user-defined source terms.

\section{H. Boundary conditions}

1. To determine the temperature distribution need to on energy equation.

2. Turbulent model is K-epsilon realizable, scalable wall function is used.

3. Working fluid water liquid with density of 998.2 $\mathrm{kg} / \mathrm{m}^{3}$ and heat exchanger pipe material is stainless steel having thermal conductivity is $\mathrm{k}=15.2 \mathrm{~W} / \mathrm{mk}$.

4. Cold inlet having mass flow rate is $0.1,0.2$ and 0.3 $\mathrm{kg} / \mathrm{sec}$, temperature $288 \mathrm{~K}$.

5. Hot inlet having mass flow rate is $0.1,0.2$ and 0.3 $\mathrm{kg} / \mathrm{sec}$, temperature $313 \mathrm{~K}$.

6. For the outlet boundary condition the gauge pressure needs to be set as zero because the fluid flowing inside the heat exchanger( hot \& cold) is atmospheric

7. Rest of all surface treated as wall with no slip conditions set for solid walls where the heat flux is set as zero for the outer side wall to make adiabatic condition, while the inner tube walls and baffles is coupled.

8. The second order upwind scheme is used for the momentum energy turbulence and its dissipation rate.

9. The Fluent solver is used for CFD analysis.
I. Computational fluid dynamics analysis for double tube heat exchanger

a. CAD model of double tube heat exchanger without baffle

In the present work a three dimensional CAD model of double tube heat exchanger is created with the help of design modular of ANSYS workbench. The inner diameter of tube is $0.01 \mathrm{~m}$, for hot fluid, inner diameter for cold fluid is $0.016 \mathrm{~m}$ with $0.001 \mathrm{~mm}$ pipe wall thickness. The length of heat exchanger is $0.1 \mathrm{~m}$. Single helical baffles with spacing of $33 \mathrm{~mm}$ pitch from top to bottom on outside of hot fluid pipe as shown in figure no. 2.

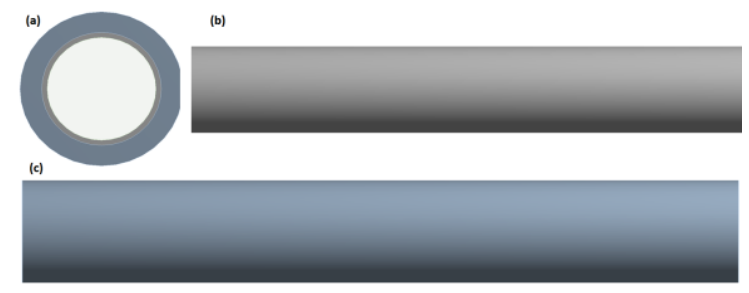

Fig. 2 CAD model of double pipe heat exchanger without baffle; (a) Face side (b) Baffle (c) Volume of cold flow

\section{b. Meshing}

Meshing is a critical operation in finite element analysis in this process CAD geometry is divided into large numbers of small pieces called mesh. The total no of nodes generated in the present work is 3289731 and total No. of Elements is 3021078 as shown in figure 3.

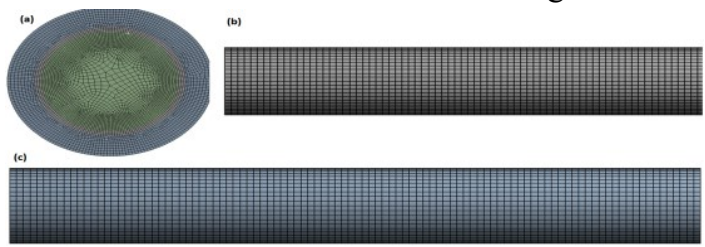

Fig. 3 Meshing of double pipe heat exchanger without baffle (a) Face side (b) Baffle (c) Volume Mesh

J. CAD model of double tube heat exchanger with single baffle at pith $B=0.033 \mathrm{~m}$

In the present work a three dimensional CAD model of double tube heat exchanger is created with the help of design modular of ANSYS workbench. The inner diameter of tube is $0.01 \mathrm{~m}$, for hot fluid, inner diameter for cold fluid is $0.016 \mathrm{~m}$ with $0.001 \mathrm{~mm}$ pipe wall thickness. The length of heat exchanger is $0.1 \mathrm{~m}$. Single helical baffles with spacing of $0.033 \mathrm{~m}$ pitch from top to bottom on outside of hot fluid pipe as shown in figure no. 4. 


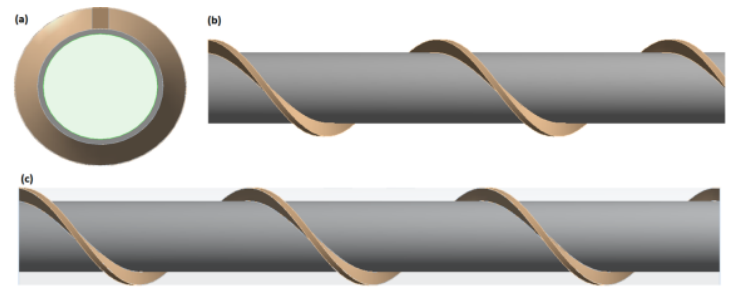

Fig. $4 \mathrm{CAD}$ model of double pipe heat exchanger with single baffle at $\mathrm{B}=0.033 \mathrm{~m}$; (a) Face side (b) Baffle (c) Volume of cold flow

\section{a. Meshing}

Meshing is a critical operation in finite element analysis in this process CAD geometry is divided into large numbers of small pieces called mesh. The total no of nodes generated in the present work is 2879962 and total No. of Elements is 2455782 as shown in figure 5.

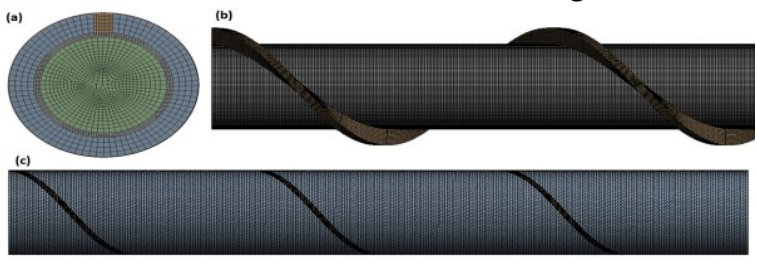

Fig. 5 Meshing of double pipe heat exchanger with single baffle at $\mathrm{B}=$ $0.033 \mathrm{~m}$; (a) Face side (b) Baffle (c) Volume Mesh

K. CAD model of double tube heat exchanger with single baffle at pith $B=0.025 \mathrm{~m}$

In the present work a three dimensional CAD model of double tube heat exchanger is created with the help of design modular of ANSYS workbench. The inner diameter of tube is $0.01 \mathrm{~m}$, for hot fluid, inner diameter for cold fluid is $0.016 \mathrm{~m}$ with $0.001 \mathrm{~mm}$ pipe wall thickness. The length of heat exchanger is $0.1 \mathrm{~m}$. Single helical baffles with spacing of $0.025 \mathrm{~m}$ pitch from top to bottom on outside of hot fluid pipe as shown in figure no.6.
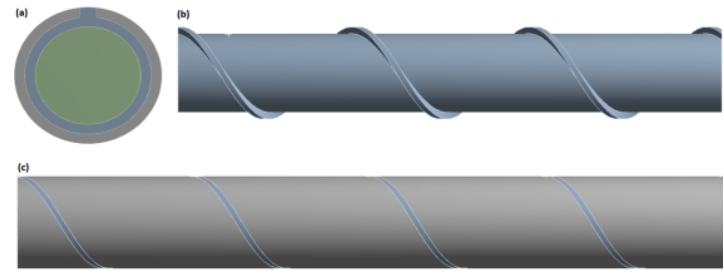

Fig. 6 CAD model of double pipe heat exchanger; (a) Face side (b) Baffle (c) Volume of cold flow

\section{a. Meshing}

Meshing is a critical operation in finite element analysis in this process CAD geometry is divided into large numbers of small pieces called mesh. The total no of nodes generated in the present work is 1108028 and total No. of Elements is 3184242 as shown in figure 7.

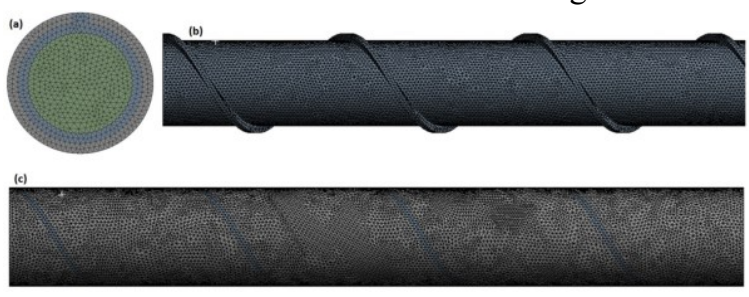

Fig. 7 meshing of double pipe heat exchanger (a) Face side (b) Baffle (c) Volume Mesh

L. CAD geometry of double tube heat exchanger with double helical baffles at pith $B=0.025 \mathrm{~m}$

In the present work a three dimensional CAD model of double tube heat exchanger is created with the help of design modular of ANSYS workbench. The inner diameter of tube is $0.01 \mathrm{~m}$, for hot fluid, inner diameter for cold fluid is $0.016 \mathrm{~m}$ with $0.001 \mathrm{~m}$ pipe wall thickness. The length of heat exchanger is $0.1 \mathrm{~m}$. Single helical baffles with spacing of $0.025 \mathrm{~m}$ pitch from top to bottom on outside of hot fluid pipe as shown in figure no 8 .

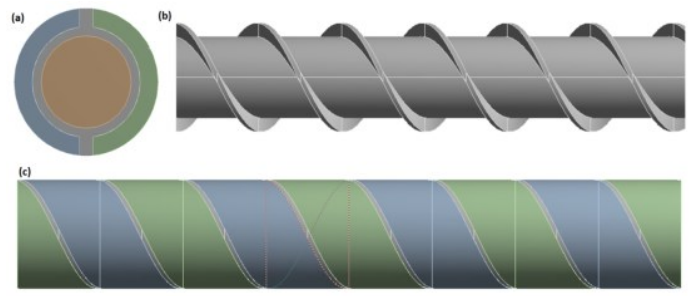

Fig. 8 CAD model of double pipe heat exchanger with two baffels; (a) Face side (b) Baffle (c) Volume of cold flow

a. Meshing

Meshing is a critical operation in finite element analysis in this process CAD geometry is divided into large numbers of small pieces called mesh. The total no of nodes generated in the present work is 2944774 and total No. of Elements is 2819506 as shown in figure 9.

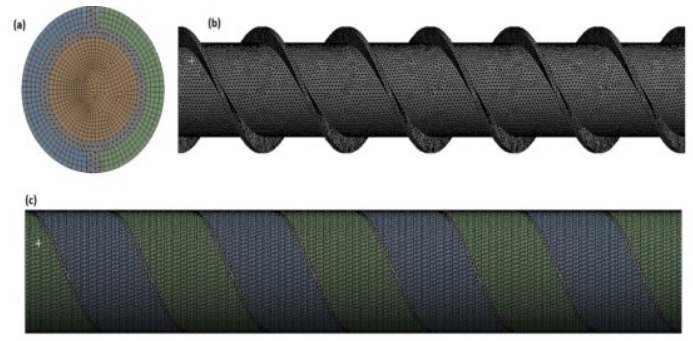

Fig. 9 Meshing of double pipe heat exchanger with two baffels; (a) Face side (b) Baffle (c) Volume Mesh

\section{Grid independent test}

Grid independent is associated with the accuracy or even rationality of numerical results. Grid-independent means calculation results change so little along with a denser or 
looser grid that the truncation error can be ignored in numerical simulation. Whether the grid is independent directly influences the truncation error or even the rationality of numerical results. When considering gridindependent test, a very dense grid can avoid this problem but the calculation resource may be wasted unnecessarily. In practice, we usually increase the grid resolution according to a certain ratio and then compare the results of two neighborhood results. If the results tend towards identical the grid can be considered as grid-independent. Such strategy can utilize computational resource most efficiently as well as obtain reasonable results.

In the present work for three dimensional double tube heat exchanger without baffle using temperature distribution and heat transfer by hot and cold fluid under condition of counter flow have been checked how numerical result converges when refining computational grid.

Heat transfer by hot fluid:

$$
Q_{h}=\dot{m}_{h} c_{p, h}\left(T_{h}^{\text {in }}-T_{h}^{\text {out }}\right)
$$

Heat gain by cold fluid:

$$
Q_{c}=\dot{m}_{c} c_{p, c}\left(T_{c}^{\text {out }}-T_{c}^{\text {in }}\right)
$$

A series of grid independent tests were carried out to ensure that optimized computational mesh was obtained. There are total six sets of grids $(37771,81874,257140$, 1627641,3021078 and 3239750 elements) are computed. It was found that the difference in the rate of heat transfer between 3021078 and 3239750 is almost similar that is why the grid system 3021078 elements were adopted.

\section{N. Interpolation relation}

Linear interpolation relation is used to find the intermediates value of specific heat of hot and cold water.

$$
y=y_{1}+\left(x-x_{1}\right) \frac{y_{2}-y_{1}}{x_{2}-x_{1}}
$$

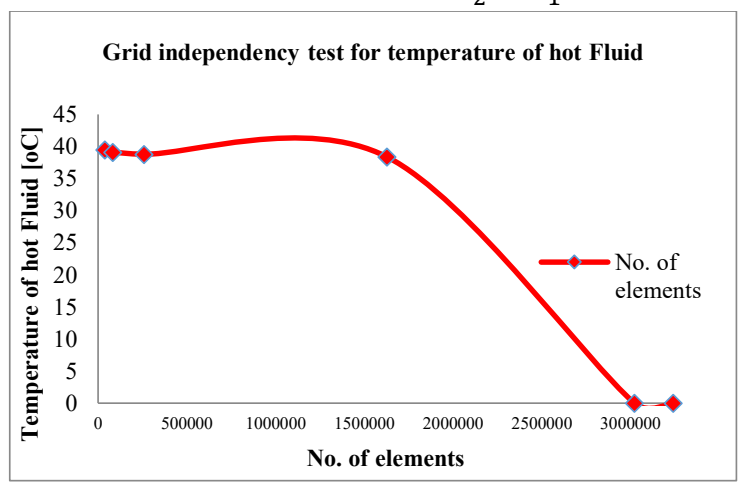

Fig. 10 Grid independency test for temperature of hot Fluid

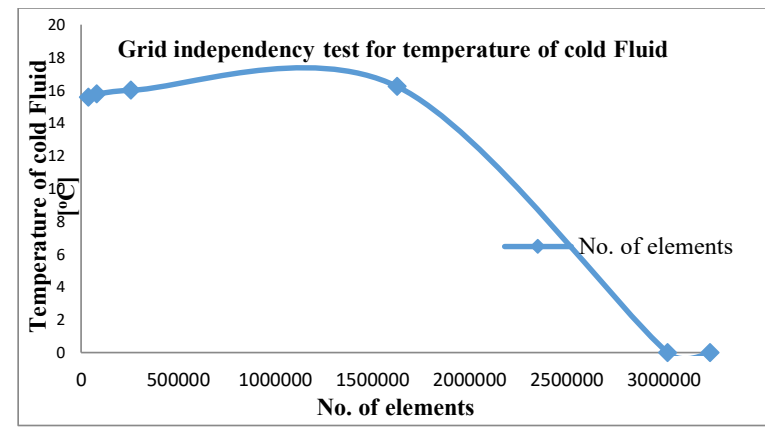

Fig. 11 Grid independency test for temperature of cold Fluid

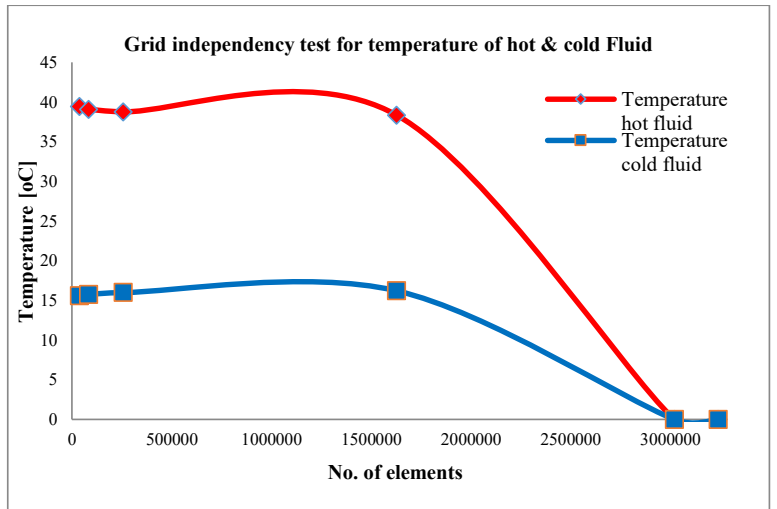

Fig. 12 Grid independency test for temperature of hot \& co0ld Fluid

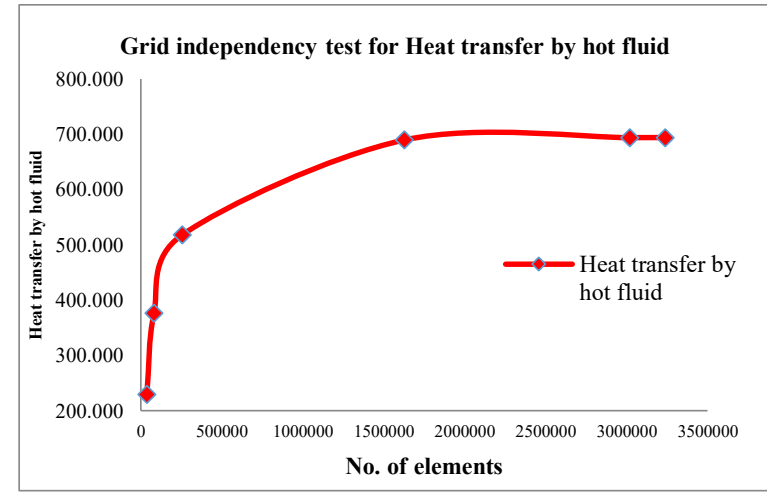

Fig. 13 Grid independency test for temperature of hot \& cold Fluid

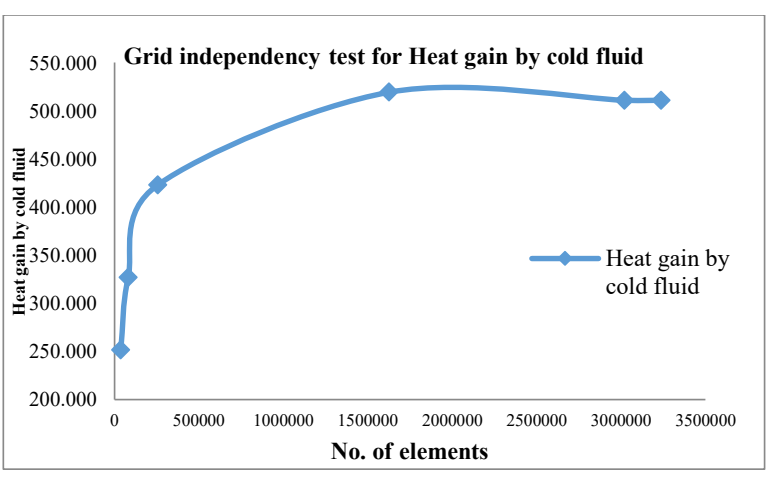

Fig. 14 Grid independency test for Heat gain by cold fluid 


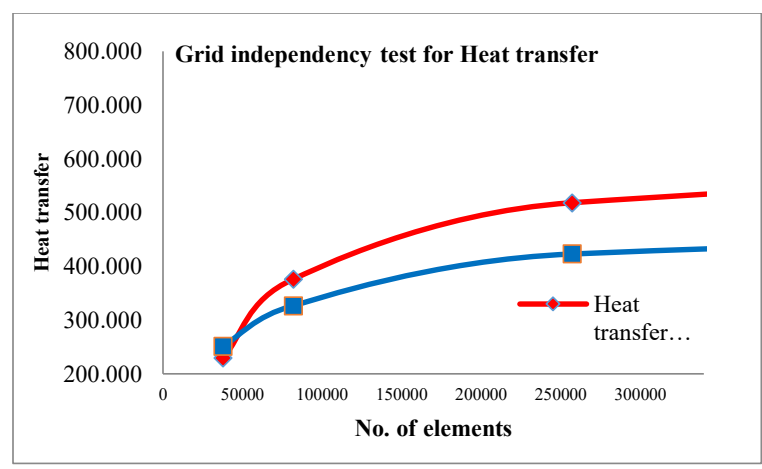

Fig. 15 Grid independency test for Heat transfer V. RESUlts

After performing computational fluid dynamics analysis of double pipe heat exchanger at different mass flow rate of hot and cold fluid varied from $0.1 \mathrm{~kg} / \mathrm{s}$ to $0.3 \mathrm{~kg} / \mathrm{s}$ while the inlet temperature of hot and cold fluid are $40^{\circ} \mathrm{C}$, and $15^{\circ} \mathrm{C}$ respectively. The variation of temperature along the heat exchanger for hot and cold flow region as shown in below contours diagram.

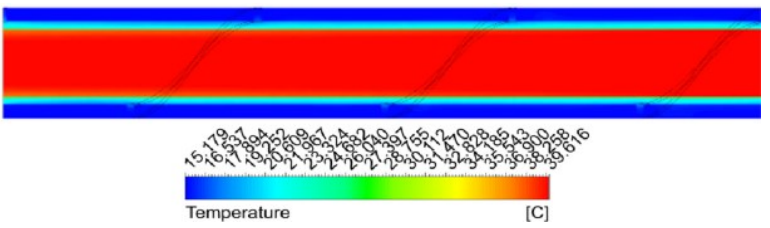

Fig. 16 Temperature contours of double pipe heat exchanger from base paper at mass flow of $0.3 \mathrm{~kg} / \mathrm{s}$ heat exchanger mid plane (xy)

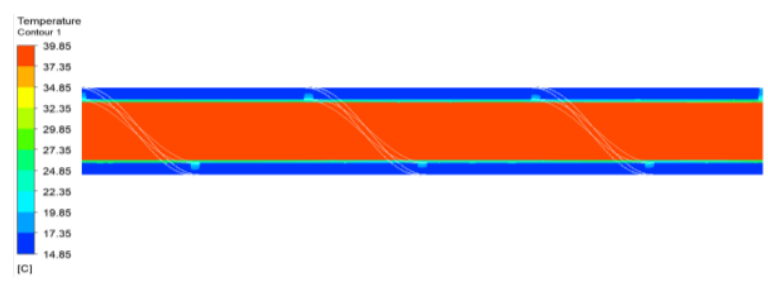

Fig. 17 Temperature contours of double pipe heat exchanger at mass flow of $0.3 \mathrm{~kg} / \mathrm{s}$ heat exchanger mid plane
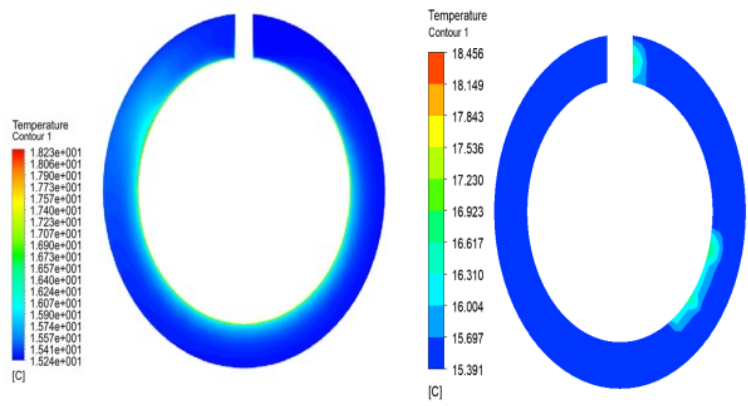

Fig. 18 Temperature contours for outer (cold) fluid at mass flow of 0.3 $\mathrm{kg} / \mathrm{s}$
After performing computational fluid dynamics analysis of double pipe heat exchanger at different mass flow rate of hot and cold fluid the velocity streamlines along the heat exchanger for cold flow region as shown in below contours diagram.

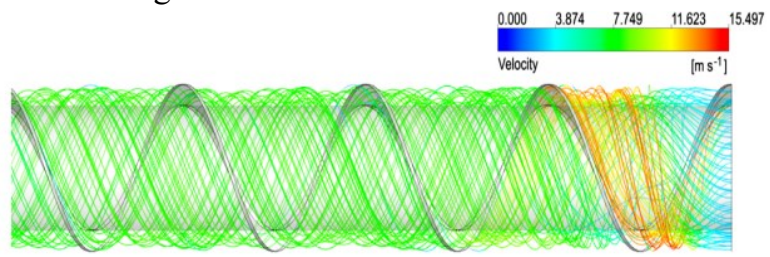

Fig. 19 Velocity streamlines at mass flow $0.3 \mathrm{~kg} / \mathrm{s}$ from base paper

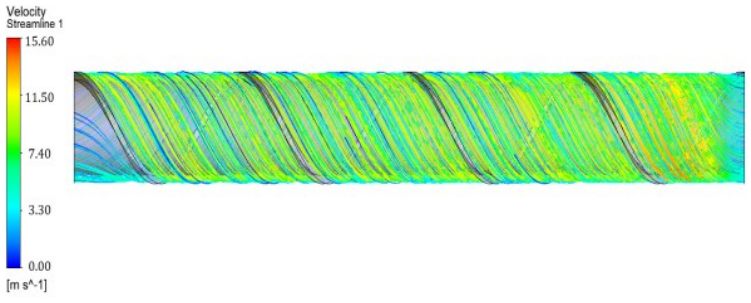

Fig. 20 Velocity streamlines at mass flow $0.3 \mathrm{~kg} / \mathrm{s}$

It has been observed that the maximal velocity of the cold fluid flowing in annulus side is near the inlet at the entrance region because of the sudden reduction in the flow area.

From the above validation work it has been observed that the compared result of temperature variation in cold fluid is about $1.23 \%$ and variation in velocity less than $1 \%$ from base paper which shows very good agreement with $1.23 \%$ error. After the validation from base model some other designs of double pipe heat exchanger have been used for computational fluid dynamics analysis to enhance the thermal performance of the double pipe heat exchanger. It has been observed that the helically baffled in the laminar flow provides a better heat transfer characteristics then turbulent flow hence rest of all computational fluid dynamic analysis will performed using laminar flow.

A. Computational fluid dynamics analysis for double pipe heat exchanger without baffles at $0.1 \mathrm{~kg} / \mathrm{sec}$ mass flow rate:

After performing computational fluid dynamics analysis of double pipe heat exchanger without baffles, cold fluid flowing at $0.1 \mathrm{~kg} / \mathrm{sec}$ while the inlet temperature of hot and cold fluid are $40^{\circ} \mathrm{C}$, and $15^{\circ} \mathrm{C}$ respectively. The hot fluid temperatures drop of $4.15 \%$ \& cold fluid temperature rise of $7.5 \%$. The variation of temperature along the heat exchanger for hot and cold flow region as shown in below contours diagram. 


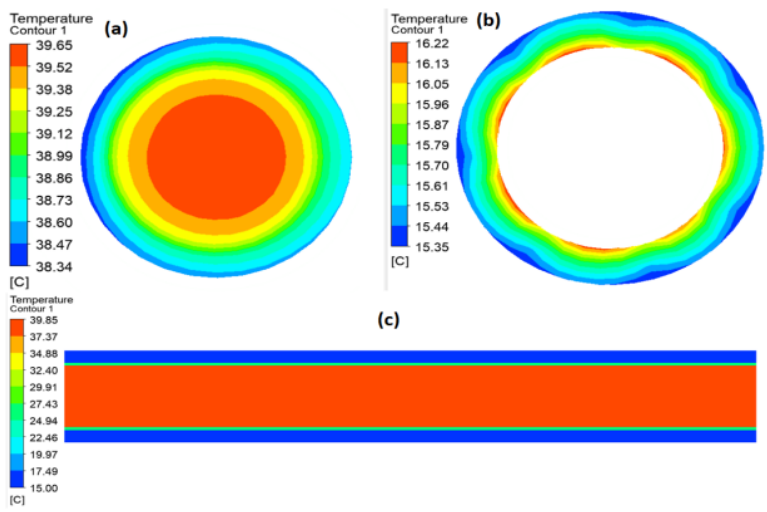

Fig. 21 temperature distribution for mass flow rate of cold fluid at 0.1 $\mathrm{kg} / \mathrm{sec}$ (a) hot fluid at outlet (b) cold fluid at outlet (c) heat exchanger mid plane

B. Computational fluid dynamics analysis for double pipe heat exchanger without baffles at $0.2 \mathrm{~kg} / \mathrm{sec}$ mass flow rate

After performing computational fluid dynamics analysis of double pipe heat exchanger without baffles, cold fluid flowing at $0.2 \mathrm{~kg} / \mathrm{sec}$ while the inlet temperature of hot and cold fluid are $40^{\circ} \mathrm{C}$, and $15^{\circ} \mathrm{C}$ respectively. The hot fluid temperatures drop of $4.95 \%$ \& cold fluid temperature rise of $3.4 \%$. The variation of temperature along the heat exchanger for hot and cold flow region as shown in below contours diagram.

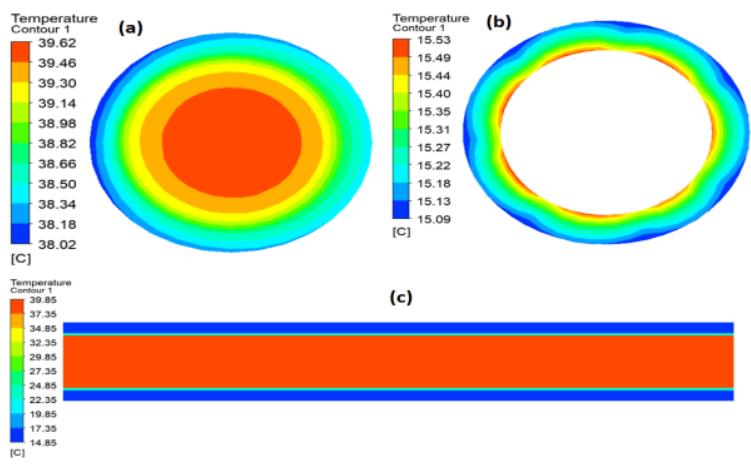

Fig. 22 temperature distribution for mass flow rate of cold fluid at 0.2 $\mathrm{kg} / \mathrm{sec}$ (a) hot fluid at outlet (b) cold fluid at outlet (c) heat exchanger mid plane

C. Computational fluid dynamics analysis for double pipe heat exchanger without baffles at $0.3 \mathrm{~kg} / \mathrm{sec}$ mass flow rate

After performing computational fluid dynamics analysis of double pipe heat exchanger without baffles, cold fluid flowing at $0.3 \mathrm{~kg} / \mathrm{sec}$ while the inlet temperature of hot and cold fluid are $40^{\circ} \mathrm{C}$, and $15^{\circ} \mathrm{C}$ respectively. The hot fluid temperatures drop of $5.3 \%$ \& cold fluid temperature rise of $2.09 \%$. The variation of temperature along the heat exchanger for hot and cold flow region as shown in below contours diagram.

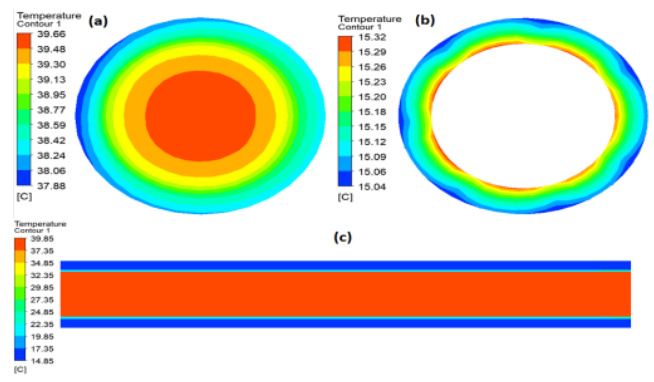

Fig. 23 temperature distribution for mass flow rate of cold fluid at 0.3 $\mathrm{kg} / \mathrm{sec}$ (a) hot fluid at outlet (b) cold fluid at outlet (c) heat exchanger mid plane

D. Computational fluid dynamics analysis for double pipe heat exchanger with single baffles of $25 \mathrm{~mm}$ pitch length at $0.1 \mathrm{~kg} / \mathrm{sec}$ mass flow rate

After performing computational fluid dynamics analysis of double pipe heat exchanger with single baffles, cold fluid flowing at $0.1 \mathrm{~kg} / \mathrm{sec}$ while the inlet temperature of hot and cold fluid are $40^{\circ} \mathrm{C}$, and $15^{\circ} \mathrm{C}$ respectively. The hot fluid temperatures drop of $4.55 \%$ \& cold fluid temperature rise of $11.5 \%$. The variation of temperature along the heat exchanger for hot and cold flow region as shown in below contours diagram.

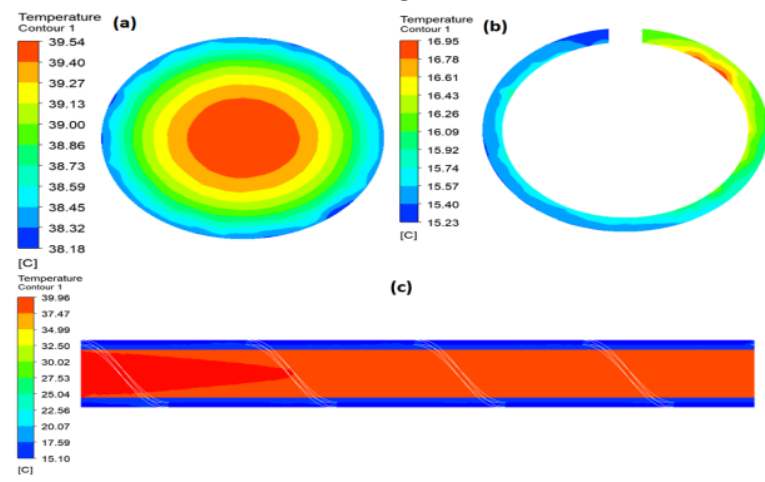

Fig. 24 Temperature contours for $\mathrm{B}=25 \mathrm{~mm}$ at mass flow rate $0.1 \mathrm{~kg} / \mathrm{s}$ (a) hot fluid at outlet (b) cold fluid at outlet (c) heat exchanger mid plane

E. Computational fluid dynamics analysis for double pipe heat exchanger with single baffles of $25 \mathrm{~mm}$ pitch length at $0.2 \mathrm{~kg} / \mathrm{sec}$ mass flow rate

After performing computational fluid dynamics analysis of double pipe heat exchanger with single baffles, cold fluid flowing at $0.2 \mathrm{~kg} / \mathrm{sec}$ while the inlet temperature of hot and cold fluid are $40^{\circ} \mathrm{C}$, and $15^{\circ} \mathrm{C}$ respectively. The hot fluid temperatures drop of $7.6 \%$ \& cold fluid temperature rise of $14.53 \%$. The variation of temperature along the heat exchanger for hot and cold flow region as shown in below contours diagram. 


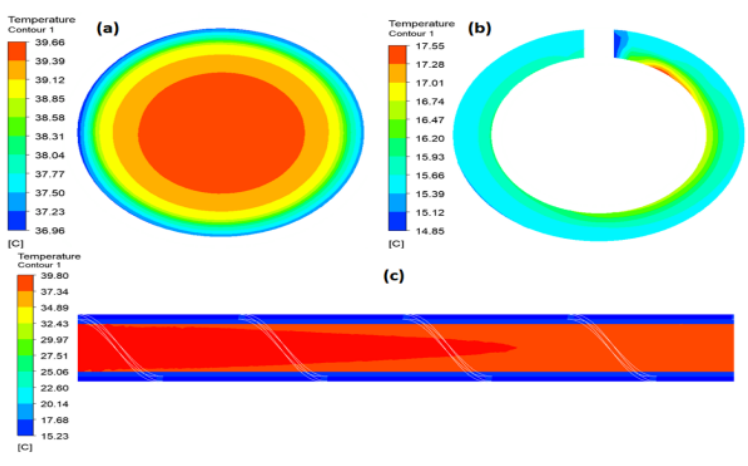

Fig. 25 Temperature contours for $B=25 \mathrm{~mm}$ at mass flow rate $0.2 \mathrm{~kg} / \mathrm{s}$ (a) hot fluid at outlet (b) cold fluid at outlet (c) heat exchanger mid plane

F. Computational fluid dynamics analysis for double pipe heat exchanger with single baffles of $25 \mathrm{~mm}$ pitch length at $0.3 \mathrm{~kg} / \mathrm{sec}$ mass flow rate

After performing computational fluid dynamics analysis of double pipe heat exchanger with single baffles, cold fluid flowing at $0.3 \mathrm{~kg} / \mathrm{sec}$ while the inlet temperature of hot and cold fluid are $40^{\circ} \mathrm{C}$, and $15^{\circ} \mathrm{C}$ respectively. The hot fluid temperatures drop of $10.075 \%$ \& cold fluid temperature rise of $20.88 \%$. The variation of temperature along the heat exchanger for hot and cold flow region as shown in below contours diagram.

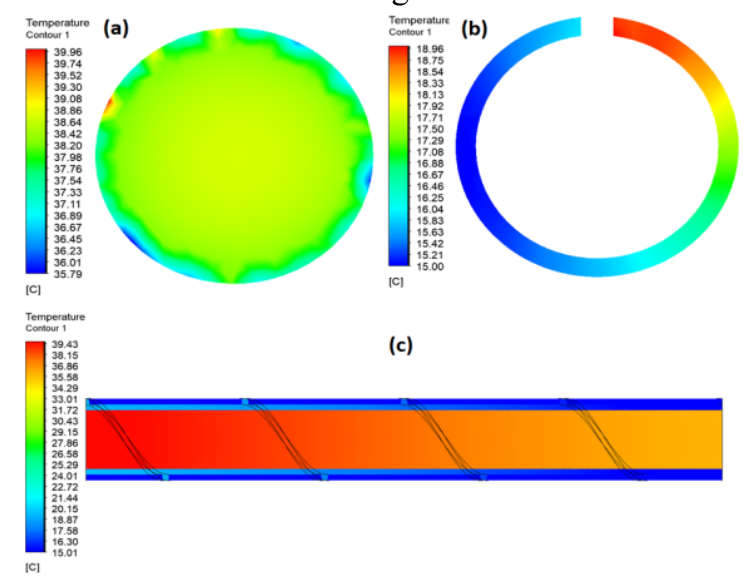

Fig. 26 Temperature contours for $B=25 \mathrm{~mm}$ at mass flow rate $0.3 \mathrm{~kg} / \mathrm{s}$ (a) hot fluid at outlet (b) cold fluid at outlet (c) heat exchanger mid plane

G. Computational fluid dynamics analysis for double pipe heat exchanger with double baffles of pitch length $25 \mathrm{~mm}$ at $0.1 \mathrm{~kg} / \mathrm{sec}$ mass flow rate

After performing computational fluid dynamics analysis of double pipe heat exchanger with double baffles, cold fluid flowing at $0.1 \mathrm{~kg} / \mathrm{sec}$ while the inlet temperature of hot and cold fluid are $40^{\circ} \mathrm{C}$, and $15^{\circ} \mathrm{C}$ respectively. The hot fluid temperatures drop of $30.25 \%$ \& cold fluid temperature rise of $45.45 \%$. The variation of temperature along the heat exchanger for hot and cold flow region as shown in below contours diagram.

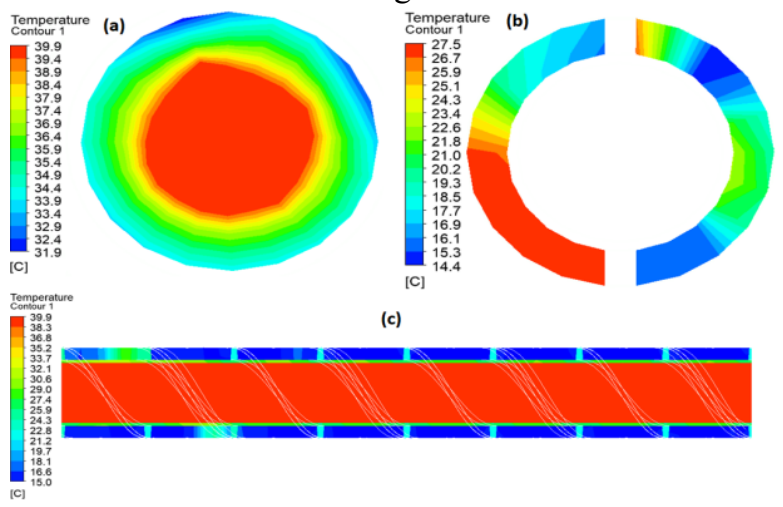

Fig. 27 Temperature contours for double baffle at $\mathrm{B}=25 \mathrm{~mm}$ at mass flow rate $0.1 \mathrm{~kg} / \mathrm{s}$ (a) hot fluid at outlet (b) cold fluid at outlet (c) heat exchanger mid plane

H. Computational fluid dynamics analysis for double pipe heat exchanger with double baffles of pitch length $25 \mathrm{~mm}$ at $0.2 \mathrm{~kg} / \mathrm{sec}$ mass flow rate

After performing computational fluid dynamics analysis of double pipe heat exchanger with double baffles, cold fluid flowing at $0.2 \mathrm{~kg} / \mathrm{sec}$ while the inlet temperature of hot and cold fluid are $40^{\circ} \mathrm{C}$, and $15^{\circ} \mathrm{C}$ respectively. The hot fluid temperatures drop of $28.75 \%$ \& cold fluid temperature rise of $43.39 \%$. The variation of temperature along the heat exchanger for hot and cold flow region as shown in below contours diagram.

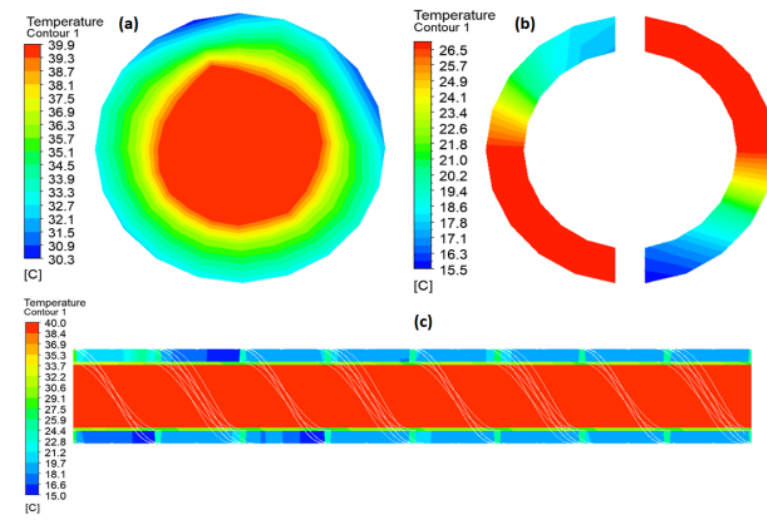

Fig. 28 Temperature contours for double baffle at $\mathrm{B}=25 \mathrm{~mm}$ at mass flow rate $0.2 \mathrm{~kg} / \mathrm{s}$ (a) hot fluid at outlet (b) cold fluid at outlet (c) heat exchanger mid plane

I. Computational fluid dynamics analysis for double pipe heat exchanger with double baffles of pitch length $25 \mathrm{~mm}$ at $0.3 \mathrm{~kg} / \mathrm{sec}$ mass flow rate

After performing computational fluid dynamics analysis of double pipe heat exchanger with double baffles, cold fluid flowing at $0.3 \mathrm{~kg} / \mathrm{sec}$ while the inlet temperature of hot and cold fluid are $40^{\circ} \mathrm{C}$, and $15^{\circ} \mathrm{C}$ respectively. The hot fluid temperatures drop of $29.75 \%$ \& cold fluid 
temperature rise of $44.23 \%$. The variation of temperature along the heat exchanger for hot and cold flow region as shown in below contours diagram.

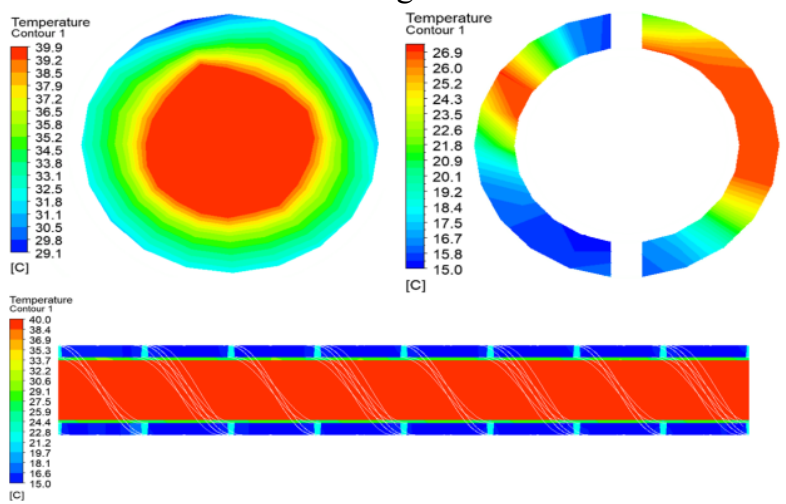

Fig. 29 Temperature contours for double baffle at $\mathrm{B}=25 \mathrm{~mm}$ at mass flow rate $0.3 \mathrm{~kg} / \mathrm{s}$ (a) hot fluid at outlet (b) cold fluid at outlet (c) heat exchanger mid plane

J. Comparative result analysis of double pipe heat exchanger

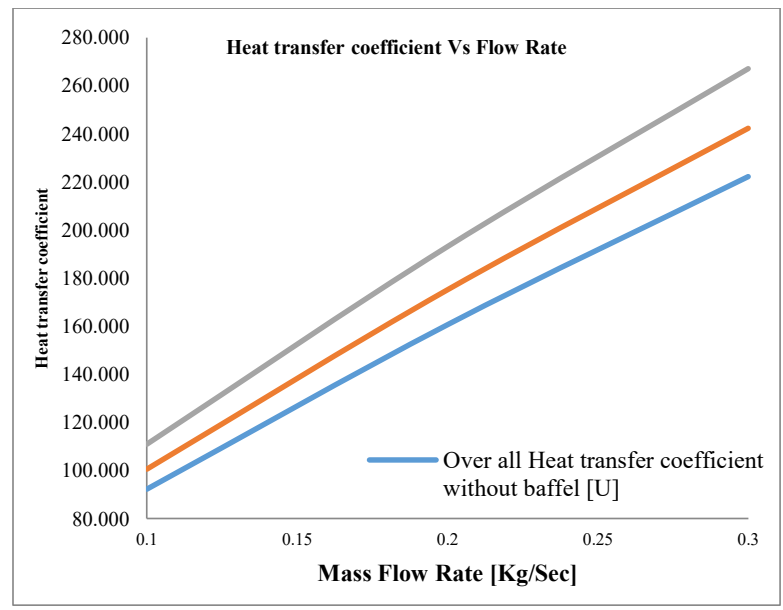

Fig. 30 Heat transfer coefficient Vs Flow Rate

Above figure represents the comparisons of the heat transfer coefficient for cold fluid of double pipe heat exchanger. It can be observed that the heat transfer coefficient increasing with the increasing in the mass flow rate of cold fluid. The overall heat transfer coefficients differ significantly by $20.4 \%$ at $0.3 \mathrm{~kg} / \mathrm{sec}$ mass flow rate, because the considerable difference between heat transfer surface area on the inner and outer side of the tube resulting in a prominent thermal enhancement of the cold fluid.

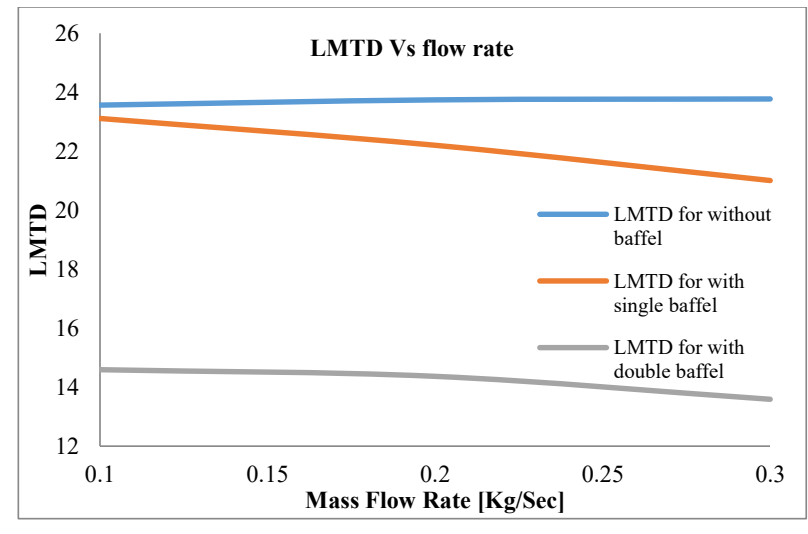

Fig. 31 LMTD Vs flow rate

Logarithmic mean temperature difference is use to determine the rate of heat transfer in heat exchanger. The temperature difference between the two fluid decrease from $\Delta T_{1}$ at the inlet to $\Delta T_{2}$ at the outlet. The logarithmic mean temperature difference is decreasing from $23.5^{\circ} \mathrm{C}$ to $13.59^{\circ} \mathrm{C}$ with increasing mass flow rate thus resulting increasing in overall heat transfer coefficient.

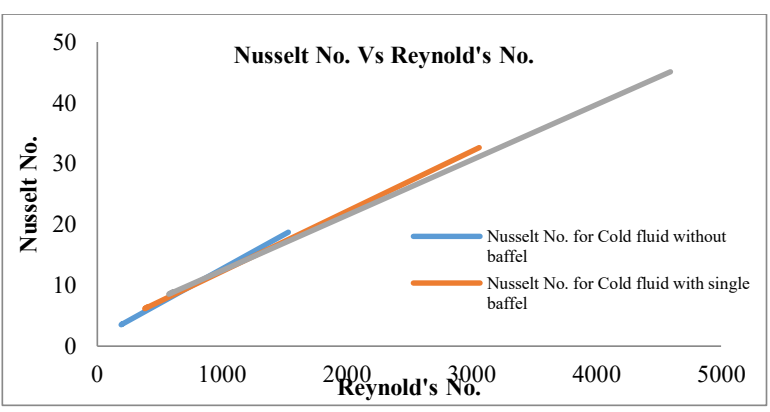

Fig. 32 Nusselt No. Vs Reynold's No.

It has been observed that the $\mathrm{Nu}$ increasing with increasing Reynolds number because of higher fluid velocities when using continuous helical baffles. Thus, the use of the baffles in the outer fluid pipe improves heat transfer due to turbulence. Turbulence enhancement increases the Reynolds number and increase in $\mathrm{Nu}$ for the same mass flow rate. It has been also observed that for the same mass flow rate the heat transfer improves with smaller baffle spacing. 


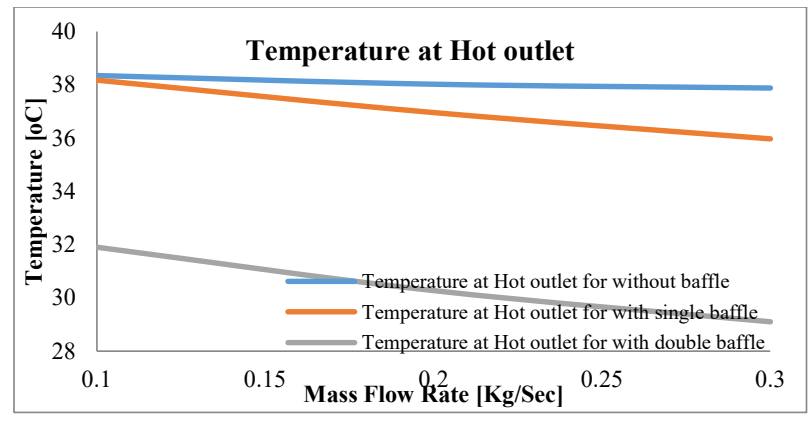

Fig. 33 Temperature at Hot outlet

It has been observed that the temperature of hot fluid is decreasing with increasing mass flow rate of cold fluid, maximum the temperature difference enhance the heat transfer rate. The maximum temperature drop of $10.9^{\circ} \mathrm{C}$ (27.25\%) for hot fluid is observed at $.3 \mathrm{~kg} / \mathrm{sec}$ mass flow rate.

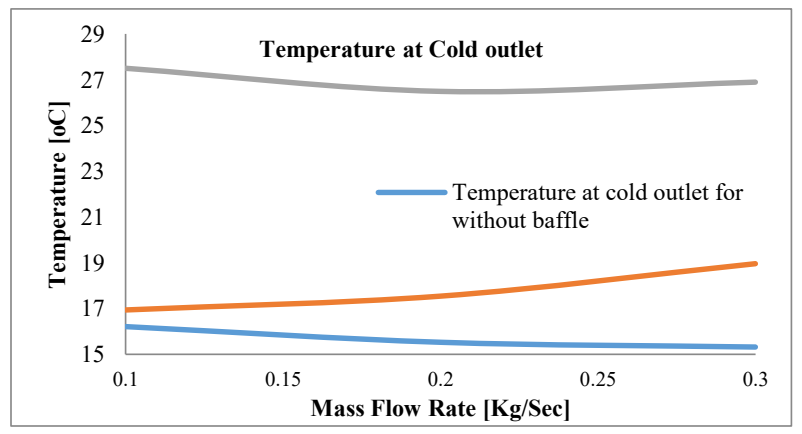

Fig. 34 Temperature at Cold outlet

It has been observed that the temperature of cold fluid is increasing with increasing mass flow rate of cold fluid, maximum the temperature difference enhance the heat transfer rate. The maximum temperature rise of $11.9^{\circ} \mathrm{C}$ ( $44.23 \%$ ) for cold fluid is observed at $.3 \mathrm{~kg} / \mathrm{sec}$ mass flow rate.

\section{CONCLUSION}

In the present work computational fluid dynamics analyses have been performed for double pipe exchanger used helical baffles with different spacing on the hot fluid pipe. For this analysis double pipe heat exchangers are divided into three different domains such as two fluid domains hot fluid in the inner tube and cold fluid in the outer pipe and a solid domain as helical baffles on inner tube of hot fluid. Mass flow rate cold fluid was varied from $0.1 \mathrm{~kg} / \mathrm{s}$ to $0.3 \mathrm{~kg} / \mathrm{s}$ while the flow rate in the inner tube i.e. hot water was kept constant at $0.1 \mathrm{~kg} / \mathrm{s}$. the inlet temperature of hot fluid taken as $40^{\circ} \mathrm{C}$ while Cold fluid inlet temperature taken as $15^{\circ} \mathrm{C}$. Mathematical and computational fluid dynamic analyses have been performed and compared the results. There are following conclusive points drawn from this work.

1. After performing computational fluid dynamics analysis of double pipe heat exchanger without baffles, cold fluid flowing at $0.1 \mathrm{~kg} / \mathrm{sec}$. The hot fluid temperatures drop of $38.34{ }^{\circ} \mathrm{C} \&$ cold fluid temperature rise of $16.22^{\circ} \mathrm{C}$.

2. After performing computational fluid dynamics analysis of double pipe heat exchanger without baffles, cold fluid flowing at $0.2 \mathrm{~kg} / \mathrm{sec}$. The hot fluid temperatures drop of $38.02{ }^{\circ} \mathrm{C} \&$ cold fluid temperature rise of $15.53{ }^{\circ} \mathrm{C}$.

3. After performing computational fluid dynamics analysis of double pipe heat exchanger without baffles, cold fluid flowing at $0.3 \mathrm{~kg} / \mathrm{sec}$. The hot fluid temperatures drop of $37.88{ }^{\circ} \mathrm{C} \&$ cold fluid temperature rise of $15.32^{\circ} \mathrm{C}$.

4. After performing computational fluid dynamics analysis of double pipe heat exchanger with single baffles, cold fluid flowing at $0.1 \mathrm{~kg} / \mathrm{sec}$. The hot fluid temperatures drop of $38.18{ }^{\circ} \mathrm{C} \&$ cold fluid temperature rise of $16.95^{\circ} \mathrm{C}$.

5. After performing computational fluid dynamics analysis of double pipe heat exchanger with single baffles, cold fluid flowing at $0.2 \mathrm{~kg} / \mathrm{sec}$. The hot fluid temperatures drop of $36.96{ }^{\circ} \mathrm{C} \&$ cold fluid temperature rise of $17.55^{\circ} \mathrm{C}$.

6. After performing computational fluid dynamics analysis of double pipe heat exchanger with single baffles, cold fluid flowing at $0.3 \mathrm{~kg} / \mathrm{sec}$. The hot fluid temperatures drop of $35.97{ }^{\circ} \mathrm{C} \&$ cold fluid temperature rise of $18.96^{\circ} \mathrm{C}$.

7. After performing computational fluid dynamics analysis of double pipe heat exchanger with double baffles, cold fluid flowing at $0.1 \mathrm{~kg} / \mathrm{sec}$. The hot fluid temperatures drop of $31.9{ }^{\circ} \mathrm{C} \&$ cold fluid temperature rise of $27.5^{\circ} \mathrm{C}$.

8. After performing computational fluid dynamics analysis of double pipe heat exchanger with double baffles, cold fluid flowing at $0.2 \mathrm{~kg} / \mathrm{sec}$. The hot fluid temperatures drop of $30.27{ }^{\circ} \mathrm{C} \&$ cold fluid temperature rise of $26.5^{\circ} \mathrm{C}$.

9. After performing computational fluid dynamics analysis of double pipe heat exchanger with double baffles, cold fluid flowing at $0.3 \mathrm{~kg} / \mathrm{sec}$. The hot fluid temperatures drop of $29.1{ }^{\circ} \mathrm{C} \&$ cold fluid temperature rise of $26.9^{\circ} \mathrm{C}$. 
10. The logarithmic mean temperature difference is decreasing from $23.5^{\circ} \mathrm{C}$ to $13.59^{\circ} \mathrm{C}$ with increasing mass flow rate thus resulting increasing in overall heat transfer coefficient.

11. The overall heat transfer coefficients differ significantly by $20.4 \%$ at $0.3 \mathrm{~kg} / \mathrm{sec}$ mass flow rate, because the considerable difference between heat transfer surface area on the inner and outer side of the tube resulting in a prominent thermal enhancement of the cold fluid.

From the above concluding points it can be summarized that the maximum temperature drop of $10.9^{\circ} \mathrm{C}(27.25 \%)$ for hot fluid and the maximum temperature rise of $11.9^{\circ} \mathrm{C}$ $(44.23 \%)$ for cold fluid are observed at $0.3 \mathrm{~kg} / \mathrm{sec}$ mass flow rate for double pipe heat exchanger with double helical baffles. It has been also observed that the heat transfer coefficient increasing with the increasing in the mass flow rate of cold fluid. The overall heat transfer coefficients differ significantly by $20.4 \%$ at same mass flow rate, because the considerable difference between heat transfer surface area on the inner and outer side of the tube resulting in a prominent thermal enhancement of the cold fluid.

\section{FUTURE SCOPE}

The main aim of present work to compare different configurations of helical baffles in the cold fluid side of a double tube heat exchanger. The addition of these geometrical features changes the pressure and velocity distribution along the cold fluid side of the heat exchanger and thus the amounts of heat transfer rate and pressure drop changes. The hot water flows inside the heat exchanger tube, while the cold fluid flows in the outer side in the direction of counter flow. Though this study is performed with utmost sincerity then also there is scope for further improvement. Some of the suggestions for future study might be possible are explained.

1. In the present work CFD analysis are performed on three different designs of double pipe heat exchanger with helical baffles but some other designs may also be used for future improvement.

2. Variable dimensions of the tubes may also be used to investigate the effect on heat transfer characteristics.

3. In the present work stainless steel is used as tube material but some other materials may also use to study for future improvement.

\section{REFERENCES}

[1] Qianmei Fu at el. "Numerical Simulation of Heat Transfer Performance between Molten Salt and Supercritical $\mathrm{CO} 2$ in Double-pipe Heat Exchanger" 10th International Conference on Applied Energy, Hong Kong, China Energy Procedia, Vol. 158, Year 2019, Page from 5741-5746.

[2] Ganesh Kumar Poongavanam at el. "Experimental investigation on heat transfer and pressure drop of MWCNT - solar glycol based nanofluids in shot peened double pipe heat exchanger" Accepted on: 18 January 2019.

[3] Rafał Andrzejczyk, Tomasz Muszynski \& Przemyslaw Kozak "Experimental investigation of heat transfer enhancement in straight and Ubend double-pipe heat exchanger with wire insert" Chemical Engineering \& Processing: Process Intensification, Vol. 136, year 2019, page from 177-190.

[4] Anas El Maakoul at el. "Numerical design and investigation of heat transfer enhancement and performance for an annulus with continuous helical baffles in a double-pipe heat exchanger" Energy Conversion and Management, vol. 133, year 2017, page from 7686.

[5] Yadav, S., \& Sahu, S. K. "Heat transfer augmentations in double pipe water to air counter flow heat exchanger with helical surface disc turbulators" Chemical Engineering and Processing: Process Intensification. Vol. 135, year 2019, page from 120-132.

[6] M. Sridharan, R. Devi, C.S. Dharshini \& M. Bhavadarani "IoT based performance monitoring and control in counter flow double pipe heat exchanger" Internet of Things Vol. 5, Year 2019, page from 34-40.

[7] Xue Chen at el. "Conjugated heat transfer analysis of a foam filled double-pipe heat exchanger for high-temperature application" International Journal of Heat and Mass Transfer Vol. 134, Year 2019, Page from 1003-1013.

[8] Wei Wang, Yaning Zhang, Kwan-Soo Lee \& Bingxi Li "Optimal design of a double pipe heat exchanger based on the outward helically corrugated tube" International Journal of Heat and Mass Transfer Vol. 135, Year 2019, page from 706-716.

[9] Heydar Maddah at el. "Factorial experimental design for the thermal performance of a double pipe heat exchanger using Al2O3-TiO2 hybrid nanofluid" International Communications in Heat and Mass Transfer, Vol. 97, year 2018, page from 92-102.

[10] Mohammad Mahdi Heyhat, Adel Abdi \& Ali Jafarzad "Performance Evaluation and Exergy Analysis of a Double Pipe Heat Exchanger under Air Bubble Injection” Accepted on: 27 July 2018, Applied Thermal Engineering, 2018. 